UDC $130.12+17.032 .2+37.01$

DOI: https://doi.org/10.30839/2072-7941.2018.149632

\title{
THE ONLY WAY TO SAVE HUMANITY FROM TOTAL COLLAPSE - NOOTECHNOLOGIES AND NOOSCIENCES
}

\author{
(C) KORSAK, K. V. \\ Kiev medical university (private) (Kyiv, Ukraine) \\ E-mail: kvkorsak@gmail.com, ORCID: 0000-0001-7715-9720 \\ (C) KORSAK, Y. K. \\ Institute of Higher Education of NAPS (Kyiv, Ukraine) \\ E-mail: olte@ukr.net, ORCID: 0000-0001-8511-0556
}

\begin{abstract}
The urgency of the research topic lies in the author's search for the elimination of environmental and other threats to the existence of mankind. The population of Homo Sapiens increases quantitatively, intensify the rate of degradation of the natural environment and accelerates the movement to the total Collapse. Scientists in the world create only "appeals" and "warnings" of danger, but even the UN decision and three environmental forums 1992, 2002 and 2012 do not indicate real means of salvation. The purpose of the study is a critical analysis of the works of scientists of the world and their environmental projects and plans. The objectives of the study are to offer a real way of saving humanity through the replacement of industrial technologies with environmentally safe nootechnologies, the development and use of the noosciences. The methodology of the study is based on the authors' foundations of the basis of many new exact and humanitarian noosciences - noophilosophy, nooecology, noohistory, noosociology, noocognitiology, and others. We use the noointegral, systemic and noohistorical methods within the framework of a promising principle of global evolutionism with transdisciplinary approaches.

The result of the study is unquestionable evidence that in the flow of nanotechnologies since 2000 ecologically safe appears, which we propose to call "wise" - neotechnologies. Their number is small and the number is growing slowly, but the trends of world science evidenced by the inevitability of the victory of nootechnologies and elimination of all industrial technologies. The main result of the study is the list of noosciences and nootechnologies, which are "terms from the future". They form the Nooglossary for which we received the copyright certificate - a legal document of our author's priority.

The conclusion is that humanity will be saved not by the "third industrial revolution" by J. Rifkin and not by the "fourth" K. Schwab or "smart-activity", but by the development of the nooosciences (noowave No. 4) and the massive use of environmentally safe nootechnologies. Nooera has already begun, but humanity does not notice it yet. The first nootechnologies exist, but they are still too small. We have created the Nooglossary to accelerate the progression of noofuture.
\end{abstract}

Key words: humanity in a crisis, ecological threats, total Collapse, means of salvation, nootechnologies, noosciences, noodevelopment, noothinking, Nooglossary

Urgency and futuroterminology. In Ukraine and all over the world socioeconomic events provoke pessimism and fear of the future. Mind of the person can operate only with known semantic units and the acquired images. It limits it prognostic possibilities to the small period of time and leads to errors in long-term predictions. The number of PhD-level 
scientists is already almost 10 million people, but they are almost always competent only in a very narrow subject and are well predicted only within it ([2;7] and others). Such scientists and even large groups are always wrong if they explore the future for an interval of 30-100 years $([3 ; 4 ; 8 ; 9 ; 11 ; 12 ; 14 ; 15]$ and others).

We are assured, that exact forecasts are possible only on the basis of the newest discoveries and application ,terms from the future". These terms and new words clearly shining the world of the future: manufacture, trade, culture, formation. An example from XX-th century physics: in the late thirties such terms there were "uranium-235" and "chain reaction". They have shined the future on tens years. A lot of scientific in the different countries at once have offered ways of management of a nuclear energy, have submitted patents for reactors and bombs.

At present the world has appeared in a feebleness stage. It fruitless global ecological forums „Rio-1992”, „Rio+10" and „Rio+20”, decisions United Nations и international organizations prove $([1 ; 5 ; 10 ; 13]$ and others). There are no successful offers of elimination of threat of a full Collapse of the world in 2050-2060th years. The main reason-absence futuroterminology, out-of-date ideologically-theoretical base of global thinking, domination of retroterms, absence futuristic concepts. Education systems are focused on the past, instead of on the future.

Article purpose. In it the complex of absolutely new concepts of positive futurological mission is offered. They form first (reduced) variant Nooglossary. These are concepts from the future, necessary for noodevelopment mankind. Our main discovery is nootechnologies and nooscience as the main means of saving a population of people and treating damage to the biosphere.

The basic material. We will consider some key terms Nooglossary, having limited for the overwhelming majority of others short definitions.

Undoubtedly, a kernel of all Nooglossary is the term „nootechnologies". It designates ecological safe ways of manufacture and extremely wise social or economic processes. Nootechnologies will allow population of people to coexist with biosphere, not damaging it and not reducing its variety. Full ecological safety nootechnologies is provided with that the person wisely directs natural processes in a desirable direction for itself, not breaking it of their normal current, not transforming them in a remover in the beginning biospheres, and later - all mankind. If people to middle XXI the item refuse industrial manufactures and will replace them nootechnologies becomes possible and a long sustainable development of a civilisation, and association of growth of number of mankind with improvement of quality of a life of each citizen.

First two nootechnologies - 1) creation of plastics as product of ability to live of bacteria eating plants and 2) transformation thanks to the phenomenon photocatalyst absorption of light quite habitual for us in very valuable process of destruction of 
biological pollution (the photocatalyst rather quickly transforms viruses or bacteria into nitrogen, water steam, carbonic gas, etc.) These two nootechnologies have been noticed by us at once after approach XXI of a century. However, the unsuccessful choice of their designation became the main reason of an inattention to them from scientific community. Only after the term invention ,nootechnologies" in 2010 there was its "statement" on the Internet and many scientific magazines of Ukraine and Russia. English-speaking editions refused to recognise the new scientific term, therefore it is absent, for example, in Science or Nature. We hope, in the future the situation will change for the better. We will specify, that in economic sciences it has appeared there were many adherents of our offer to enter for nootechnologies new and highest technological level - the seventh.

At the moment of creation by us Nooglossary existed and four were used nootechnologies - to specified to two have increased "cultivation" biological nanoslides with use of any organic waste and transformation thanks to ability to live of a certain kind of bacteria of sand or other crushed substratum in a monolith (this way already eliminate cracks in concrete or other materials of old constructions).

However

the stream nootechnologies is only at an initial stage, and among the subsequent achievements for certain will appear so important, that will render incomparably biggest influence, than together first four nootechnologies. We will be limited to one example - flexible films from the materials capable directly to transform solar beams in an electric current (photo cells of different type).

Throughout all second half of XXth century of diligence and interests of the scientific different states concentrated round silicon photo cells. They have many positive lines: are not afraid of vacuum and can be used without considerable difficulties in space as a source of an electricity for space stations with crew; round us it is a lot of raw materials for their manufacturing (silicon is included not only into sand structure, but also tens other rocks), etc. However, despite the long history, silicon photopanels and did not become very cheap and have not got very long terms of use. Even in the most developed states of the world of the government are compelled is artificial to reduce the price for silicon photo cells at the expense of the budget, as does their attractive enough, for example, for Germans or Swisses with average well-being. It is possible to confirm quite confidently - silicon photopanels never will supersede thermal or nuclear power stations from the power market.

"Break" to ecologically safe power supply has begun in 2013 after manufacturing of the first films on a basis perovskite - rather readily available connection of calcium, the titan and oxygen $\left(\mathrm{CaTiO}_{3}\right)$. Magnificently thin film perovskite has the same photoefficiency, as well as in 200-300 times thicker silicon plate. It is difficult to believe in it, but actually only 20 buckets of this extended in Russia (Hibines, Urals Mountains etc.) and Ukraine (titanic deposits of 
Volhyn and so forth) are sufficient for creation of a solar power station by capacity of 100-150 million watt. Though manufacturing techniques perovskite films are still rather imperfect, their cost already in 5-6 times less than the cheapest silicon photopanels. Not only the developed countries, but also Ukraine is quite capable to make infinite, thin and strong perovskite film photo cells with the price $20-40 \$$ for capacity thousand watt. They have two more enormous advantages: 1) react to a diffused light (the silicon should be focused on the Sun) and can cover walls of houses and facades from glass, and also to carry out a role of any fences or noise protection screens; 2) the admission of a current from an external source on perovskite to a film forces it to be shone, that can be used for manufacturing of new generation of effective light sources in a life and the industry.

Set of advantages perovskite films is so great, that available thermal or nuclear sources of the electric power in some years will disappear for ever together with the dangers of a hotbed effect created by them and very harmful pollution of biosphere by radioactive elements. Duration of a transition period will be the less, than resistance of the oil, gas, coal or other monopolies interested in an interdiction of any changes and in preservation of own profits will be weaker.

Let's finish the analysis „perovskite" an example to one important cautions: at present the manufacturing techniques of films yet did not become nootechnologies though the volume of its harmful payment in available environmental problems in thousand times is less, than in case of modern industrial means of reception of the same quantity of electric energy by means of coal, oil, gas or nuclear power stations. And here in the future transition to organic photo cells will give the chance to "grow up" true and solar power stations, and even to create a network of transportation of energy to consumers - all it is in ecologically safe image. Modern organic photo cells are still rather imperfect, therefore do not create a competition perovskite, to traditional energy sources.

The main result of the study is the list of noosciences and nootechnologies, which are "terms from the future". They form the Nooglossary for which we received the copyright certificate - a legal document of our author's priority [6].

\section{Nooglossary}

Key terms of Nooglossary

1. Nootechnologies - the industrial and other means representing natural processes wisely operated by the person, capable to exclude any harm for biosphere and the person. For nootechnologies it is necessary to create special - the 7 th technological level.

2. Noodevelopment - mankind progress on a basis of nootechnologies, making possible association for growth of its number with improvement of quality and safety of life for each person.

3. Noosociety - a new stage of the mankind, which life-support will be based on nootechnologies with a simultaneous interdiction of industrial 
and other ecologically harmful manufactures.

Other terms of Nooglossary (in alphabetic order)

Nooactivity - the use of nootechnologies in manufacture with the simultaneous account of advanced achievements in the humanities

Nooadaptation - process of the wise and active adaptation of the person or social group to the social environment.

Nooaestetics - an aesthetics for noosociety.

Nooaltruism - the disinterested aspiration to wise activity for the blessing of others, readiness for the sake of it to renounce own interests. It can become the mass phenomenon only in conditions of noosociety.

Nooantropogen - the modern period of geological history of the Earth and the mankind evolution, having begun on border of the 2000 after occurrence of the first nootechnologies.

Nooantroposphere - a part of biosphere which represents set of all people of the globe whose ability to live is based on nootechnologies.

Nooarshitecture - building art; designing and building of constructions on a basis of nootechnologies.

Nooart - art oin the time of noosociety, subordinated to principles of noomoral, nooestethics, nootutoring, to positions of world conventions „On Duties of the Person”, „About Human Rights”, „On Protection of Children", etc.

Nooautonomy - self-management on the basis of wisdom of a certain part of the states and-or various collectives of their citizens.

Nooaxiology - a perspective variant of the doctrine about the values, leaning against achievements in nanosciences and nootechnologies.

Noobehaviour - generated by efforts of noopedagogy bases and principles of individual activity of the citizens in noosociety

Noobiology - directed on creation and use of nootechnologies; set of sciences about a life

Noobiosphere- cover of the Earth wisely operated by people who is inhabited by living organisms.

Noobusiness - a wise variant of enterprise activity.

Noocity - a place for the consolidated stay and activity of great number of people transformed by inquiries of noosociety and priorities for people in the epoch of nootechnologies

Nooculture - anthropological compound of noosociety as a set of noomaterial, social and art means and the phenomena

Noocivilazation - anthropogenous noosystem constructed after the arrival of the 4th technologicallyindustrial wave (or „noovawe”). Other name - noosociety

Noodifferentiation - wise division, a partition of the whole on qualitatively excellent parts (for example, in case of selection and a direction of schoolboys on different profiles in training and vocational training)

Nooecology - the ecological doctrine in noosociety Nooenergy the power that uses only nootechnologies.

Nooeducation - mastering of basic social and industrial 
noocompetences by young citizens in noosociety

Nooencyclopedia - set of terms and various concepts which in integrity cover all "nooquestions”

Nooera - the historical period which will cover transition and domination of nootechnologies and noosociety

Nooethology - noovariant of modern ethology as a science about the valid bases of acts and behaviour of the person during the different age periods of his life.

Nooevolution - change and development of mankind or other natural object on a basis of nootechnologies

Nooexatology - the positive scientific doctrine about destiny of mankind and the Universe in case of a full victory of nootechnologies over all others

Noofauna - fauna in epoch of noosociety as a part noobiosphere

Nooflora - flora in epoch of noosociety as a part noobiosphere

Noogender - a perfect variant of gender theories which leans against advanced achievements in sciences and the humanities

Noogeopolicy - the theory of dependence of foreign policy of the state on geographical and other factors in the conditions of an interdiction in industrial and a full victory of nootechnologies.

Nooharmony - a perfect coordination of parts of a public, industrial or natural single whole which leans against the use of nootechnologies.

Noohistory - a wise variant of historical doctrines and the sciences directed on formation and stability in noosociety

Noohouse - created on the basis of wisdom and nootechnologies human habitation

Noohumanity - realisation of principle for the relation to the person as to the highest value in conditions of noosociety and adoption of the world convention „On Duties of the Person".

Nooideology - a wise variant of public consciousness in noosociety

Nooinformation - the wise information directed on stability in noosociety

Noointellect - a wise variant of ability to thinking

Nooknowledge - a scientific basis in noosociety and nooselfmaintenance of mankind

Noolandscape - transformation of environment by the person in the epoch of nootechnologies

Noolife - the highest stage of ability to live based on the use of nootechnologies and achievements of the humanities

Nooliterature - the literature in the epoch of nootechnologies, thematically connected with its development and the statement

Noomachine - the machine in the epoch of nootechnologies, acceptable and safe for the person and anthropogenous environment in the period of noosociety

Noomanagement - a concept equivalent to "nooactivity”

Noomass-media - mass media noosociety which will operate in the conditions of observance of world conventions „On nooethics of journalism”, „About Duties of the Person" and others 
Noomaterials - ecologically safe building and any other materials in the epoch of nootechnologies

Noomaterial science - a science about materials of industrial and other appointment in the epoch of nootechnologies

Noomedicine - wise means for formation of the healthy person and support of its fruitful and long life

Noomentality - generated in the citizens of noosociety highspirited and positively exatological way of thinking and mental activity.

Noomorals - morals in the epoch of noosociety which has overcome the main lacks of the so-called ,natural morals" for Homo Sapiens

Noonetwork - wise means of information and other association and dialogue of citizens in noosociety, created on a basis of nootechnologies of quantum character

Noonursery scool - preschool centre for introductory socialisation of youth in conditions of noosociety, using advanced achievements in natural sciences and the humanities

Noooutlook - outlook of citizens in noosociety, generated by means noopedagogy and directed on conscious association of individual and universal priorities

Noopedagogy - focused on needs of noosociety an integrated science about the individualised formation, education, training and trade granting to each representative of new generations according to its natural inclinations which is intended also for the further support of the person in a current of all his adult life

Noophilosophy

the philosophical doctrine of noosociety in epoch which will get heuristic character and will overcome morallyworld outlook errors of postmodernist philosophy

Noophysics and nooscienecs - a variant of the traditional exact sciences which principle of activity is noomoral, and the purpose - creation and use of nootechnologies

Noopower - a wise variant for management of a society and support of its stability on a basis of nootechnologiecal life-support

Nooproduction - reception of desirable products by the human on the basis of ecologically safe nootechnologies

Nooprojects - improvement means in noosociety which consistently consider potential of nootechnologies and achievements of the newest sciences

Noopsychology - noovariant of psychology which unites the best achievements of classical psychology with monitoring and use of discoveries in young sciences about the person

Nooreligion - the hypothetical spiritual doctrine which will have on a basis noothinking about the Nature and a place for a person in the epoch of noosociety

Nooschool - educational institution in the epoch of noosociety

Nooself-maintenance - selfmaintenance of mankind and support for stability of biosphere on a basis of nootechnologies

Noosphere - an embodiment on a basis of nootechnologies V.I.Vernadsky's offer and his French colleagues to transform anthroposphere from ,sphere of the person" into ,wisdom sphere". 
Noospirit - noovariant for morals, religiousness, rising thoughts and actions of members in noosociety in the conditions of a full victory of nootechnologies

Noostandarts - any norms and the recommended indicators directed on formation and stability of noosociety

Noostrategy - a wise variant for foresight planning of individual and collective actions

Nooteaching - a wise and effective method of training which leans against advanced achievements in natural sciences and the humanities

Noothinking - a way of using the brain, surpassing traditional "wisdom" wider age frameworks and use not only life experience, but also the newest achievements in the exact sciences and the humanities

Nootrade - an exchange and acquisition of things and the blessings in noosociety with observance of its standards of ability to live

Nootransport - ecologically safe and perfect transport in the epoch of noosociety

Nootutoring - basic socialisation of new generations which is based on the highest achievements in natural sciences and the humanities

Nooviews - spiritual and moral bases for individual activity of the citizen in the noosociety

Conclusions and offers. Stated above allows to assert, that concentration of efforts of the governments of the states of the world on replacement industrial nooproductors forms chance of prevention of that collapse of a civilisation which with such confidence is predicted by many leaders of futurologists of the world on middle XXI of a century. But they do not know and do not represent all possibilities nootechnologies, do not know and do not use all concepts Nooglosary (Нооглоссарий) except for one - the offered by V.I.Vernadski and its French colleagues of concept "noosphere".

Abundantly clear, that the biosphere will not arise on the Earth by itself, by itself the total collapse if mass-media and sow further contention and enmity if the antiscience and frank charlatanism creates atmosphere of contempt for fundamental sciences and nootechnologies will come only.

Scientists and all other persons capable on noothincing, should intensify the conscious and coordinated efforts that the fact of occurrence of reason on the Earth did not become only bright flash which will inevitably end with a nonexistence gloom already in the near future.

Obviously that humanity will be saved not by the "third industrial revolution" by J. Rifkin and not by the "fourth" K. Schwab [7; 9] or "smartactivity" [14], but by the development of the nooosciences (noowave No. 4) and the massive use of environmentally safe nootechnologies. Nooera has already begun, but humanity does not notice it yet. The first nootechnologies exist, but they are still too small. We have created the Nooglossary to accelerate the progression of noofuture.

\section{REFERENCES}


1. European Commission. Europe 2020: A strategy for smart, sustainable and inclusive growth. COM (2010) 2020. Brussels.

2. Ford, M. (2016). Rise of the Robots: Technology and the Threat of a Jobless Future. New York: Basic Books, 368.

3. Fukuyama, F. (1992). The End of History and the Last Man. London: Hamish Hamilton, 418.

4. Gaudin, Th. (1990). 2100 recit du prochain siecle. Paris, Editions Payot, 600.

5. Johannesburg Declaration on Sustainable Development. Adopted at the 17th plenary meeting of the World Summit on Sustainable Development, on 4 September 2002, 4.

6. Korsak, K. V., Korsak, Yu. K. (2014). Svidotstvo na reyestratsiyu avtors'koho prava na tvir «Noohlosariy (nooentsyklopediya)» [(Certificate of registration of copyrights to the work "Nooglossary (nooencyclopedia)] (2014). No. 55840. Kyiv: Derzhavna sluzhba intelektual'noyi vlasnosti Ukrayiny.

7. Rifkin, J. (2011). The Third Industrial Revolution: How Lateral Power is Transforming Energy, the Economy, and the World. Palgrave Macmillan, 2011.

8. Ross, A. (2016). The Industries of the Future. New York: Simon \& Schuster.

9. Schwab, K. (2016). The Forth Industrial Revolution. Geneva: World Economic Forum, 172.

10. The Earth Summit. The United Nations Conference on Environment and Development (UNCED). Introd. and commentary by Stanley P. Johnson (1992). London: Graham and Trotman.

11. Toffler, A. (1970). Future Shock. New York: Random House, 505.

12. Toffler, A. (1980). The Third Wave. New York: William Morrow, 544.

13. Robinson, N. A. (Ed.) (1992). United Nations Conference on Environment and Development. Agenda 21 and the UNCED Proceedings. New York: Oceana.

14. Von Weizsäcker, E. U., Wijkman, A. (2018). Come On! Capitalism, Short-termism, Population and the Destruction of the Planet. Springer, 220. doi: https://doi.org/10.1007/9781-4939-7419-1

15. Ripple, W. J., Wolf, C., Newsome, T. M., Galetti, M., Alamgir, M. et. al. (2017). World Scientists' Warning to Humanity: A Second Notice. BioScience, 67 (12), 1026-1028. doi: https://doi.org/10.1093/biosci/bix125

КОРСАК, К. В. - доктор філософських наук, професор, Київський медичний університет Української асоціації народної медицини (Київ, Україна)

E-mail: kvkorsak@gmail.com, ORCID 0000-0001-7715-9720

КОРСАК, Ю. К. - кандидат філософських наук, старший науковий співробітник, Інститут вищої освіти НАПН України (Київ, Україна)

E-mail: olte@ukr.net, ORCID 0000-0001-8511-0556

\section{ЄДИНИЙ ШЛЯХ ПОРЯТУНКУ ЛЮДСТВА ВІД ТОТАЛЬНОГО КОЛАПСУ - НООТЕХНОЛОГІї ТА НООНАУКИ}

Анотація. Актуальність теми дослідження полягає в авторських пошуках шляху ліквідації екологічних та інших загроз існуванню людства. Популяція Homo Sapiens зростає кількісно, збільшує темп деструкції природного довкілля і прискорює рух до тотального Колапсу. Науковці світу створюють лише «відозви» і попередження про небезпеку, навіть рішення ООН і три екологічні форуми 1992, 2002 і 2012 не вказують реальних засобів порятунку. Мета дослідження - критичний аналіз праць науковців світу та їх екологічних проектів і планів. Цілі дослідження - пропозиція реального шляху порятунку людства через заміну індустріальних технологій екологічно безпечними ноотехнологіями, розвиток і використання ноонаук. Методологія дослідження спирається на створені авторами основи багатьох нових точних i 
гуманітарних наук - ноофілософію, нооекологію, нооісторію, ноосоціологію, ноокогнітологію та інші. Ми використовуємо нооінтегральний, системний i нооісторичний методи у межах перспективного принципу глобального еволюціонізму з трансдисциплінарними підходами.

Результат дослідження - незаперечні докази того, що у потоці нанотехнологій 3 2000 року стали з'являтися екологічно безпечні, які ми пропонуємо назвати «мудрими» - ноотехнологіями. Їх мало і кількість зростає повільно, але тренди розвитку світової науки свідчать про неминучість перемоги ноотехнологій на сучасними індустріальними. Головний результат дослідження - список ноонаук і ноотехнологій, що є «термінами 3 майбутнього». Вони формують Нооглосарій, на який ми отримали авторське свідоцтво - юридичний документ нашого авторського пріоритету.

Висновок - людство урятується не через «третю промислову революцію» Дж. Ріфкіна і не через «четверту» К. Шваба чи через «смарт-активність», а шляхом розвитку ноонаук (ноохвиля №4) i масового використання екологічно безпечних ноотехнологій. Нооера вже розпочалася, але людство цього ще не помічає. Перші ноотехнології існують, але їх ще надто мало. Ми створили Нооглосарій для прискорення ноопрогресу.

Ключові слова: людство у кризі, екологічні загрози, тотальний колапс, засоби порятунку, ноотехнології, ноонауки, ноомислення, Нооглосарій

КОРСАК, К. В. - доктор философских наук, профессор, Киевский медицинский университет Украинской ассоциации народной медицины (Киев, Украина)

E-mail: kvkorsak@gmail.com, ORCID 0000-0001-7715-9720

КОРСАК, Ю. К. - кандидат философских наук, старший научный сотрудник, Институт высшего образования НАПН Украины (Киев, Украина)

E-mail: olte@ukr.net, ORCID 0000-0001-8511-0556

\section{ЕДИНСТВЕННЫЙ ПУТЬ СПАСЕНИЯ ЧЕЛОВЕЧЕСТВА ОТ ТОТАЛЬНОГО КОЛЛАПСА - НООТЕХНОЛОГИИ И НООНАУКИ}

Аннотация. Актуальность темы исследования заключается в авторских поисках пути ликвидации экологических и других угроз существованию человечества. Популяция Homo Sapiens растет количественно, увеличивает темп деструкции природной среды и ускоряет движение к тотальному коллапсу. Ученые мира создают лишь «воззвания» и предупреждения об опасности, даже решения ООН и три экологические форума 1992, 2002 и 2012 не указывают реальных средств спасения. Задача исследования - критический анализ трудов учёных и их экологических проектов и планов. Цель исследования - предложение реального пути спасения человечества через замену индустриальных технологий экологически безопасными ноотехнологиями, развитие и использование ноонаук. Методология исследования опирается на созданные авторами основы многих новых точных и гуманитарных наук ноофилософию, нооэкологию, нооисторию, ноосоциологию, ноокогнитологию и другие. Мы используем нооинтегральний, системный и нооисторический методы в рамках перспективного принципа глобального эволюционизма с трансдисциплинарными подходами.

Результат исследования - неоспоримые доказательства того, что в потоке нанотехнологий с 2000 года стали появляться экологически безопасные, которые мы предлагаем назвать «мудрыми» - ноотехнологиями. Их мало и количество растет медленно, но тренды развития мировой науки свидетельствуют о неизбежности победы ноотехнологий над современными индустриальными. Главный результат исследования - список ноонаук и ноотехнологий, содержащий «термины из будущего». Они 
формируют Нооглоссарий, на который мы получили авторское свидетельство юридический документ нашего авторского приоритета.

Вывод - человечество спасется не через "третью промышленную революцию» Дж. Рифкина и не через «четвертую» К. Шваба или «смарт-активность», а путем развития ноонаук (нооволна №4) и массового использования экологически безопасных ноотехнологий. Нооэра уже началась, но человечество этого еще не замечает. Первые ноотехнологии существуют, но их еще слишком мало. Мы создали Нооглоссарий для ускорения ноопрогресса.

Ключевые слова: человечество в кризисе, экологические угрозы, тотальный коллапс, средства спасения, ноотехнологии, ноонауки, ноомышление, Нооглоссарий

Стаття рекомендована до публікації д.філософ.н., проф. О. П. Пунченко (Одеса, Украӥна)

Надійшла до редколегії: 12.09.2018 Прийнята до друку: 17.09.2018 